\title{
The Role the University Could Play in an Inclusive Regional Innovation System
}

\author{
Wei Yao ${ }^{1}$, Heng $\mathrm{Li}^{2^{*}}$ (D) and Mosi Weng ${ }^{2}$
}

\author{
* Correspondence: \\ leeheng@zju.edu.cn \\ ${ }^{2}$ School of Public Affairs, Zhejiang \\ University, Room 905, \\ Administration Building, Zijingang \\ CampusHangzhou, Zhejiang, \\ People's Republic of China \\ Full list of author information is \\ available at the end of the article
}

\begin{abstract}
Extant research shows that universities do not usually foster an inclusive innovation system. This paper examines an innovation program at Zhejiang University that targeted rural areas in China, and that sought to promote an inclusive innovation system. This case illuminates how universities could play a critical role in configuring inclusive regional innovation systems by means of selection, improvement and diffusion of technology, dissemination and absorption of knowledge, access to science and technology, intermediation between the actors of innovation, training skilled labor, and cultivating talent. We underscore how the inclusive innovation program of Zhejiang University allowed this university to help realize the enormous consumption, production, and entrepreneurial potential of low-income households in rural China.
\end{abstract}

Keywords: Inclusive innovation, University

\section{摘要:}

包容性增长是积极社会变革不可或缺的解决方案。在大多数过去的研究中,在 其他创新体系中起着核心作用的大学被排除在包容性创新体系之外。本文尝试 对浙江大学在中国农村开展包容性创新运作的案例研究,找到大学在区域包容 性创新体系中发挥的关键作用。结果表明,在包容性创新体系中大学能在下列 方面发挥多种关键作用:技术选择、改进和扩散，知识传播和吸收，科技知识的获 取,初级中介服务,培训熟练劳动力,教育和提供区域高层次人才。此外,包容性创 新通过充分利用贫困人群所拥有的巨大消费、生产和创业潜力，为大学提供难 以模仿的竞争优势。

关键词: 包容性创新, 大学

\section{Résumé}

La croissance inclusive est. une solution indispensable au changement social positif. Dans les recherches les plus avancées, l'université, qui joue un rôle central dans d'autres systèmes d'innovation, est. exclue du système d'innovation inclusive. Cet article tente de mener une étude de cas sur l'Université du Zhejiang qui a conduit une opération d'innovation inclusive dans les zones rurales de Chine; l'objectif est. de déterminer le rôle clé joué par l'université dans le système régional d'innovation inclusive. Les résultats montrent que les universités pourraient jouer des rôles divers et essentiels dans la sélection, l'amélioration et la diffusion de la technologie, la diffusion et l'absorption du savoir, l'accès au savoir scientifique et technologique, le service de (Continued on next page) 
(Continued from previous page)

premier intermédiaire, la formation de la main-d'œuvre qualifiée, la formation et la mise à disposition de talents de haut niveau dans les systèmes régionaux d'innovation inclusive. En outre, l'innovation inclusive offre aux universités un avantage concurrentiel difficile à imiter en leur offrant la possibilité de tirer pleinement parti de l'énorme potentiel de consommation, de production et d'entrepreneuriat des pauvres.

Mots-clés: innovation inclusive, université

\title{
Resumo
}

Crescimento inclusivo é uma solução indispensável para mudanças sociais positivas. Nas pesquisas prévias, a Universidade, que desempenha um papel central em outros sistemas de inovação, é excluída de sistemas de inovação inclusiva. Este artigo realiza uma tentativa de condução de um caso de estudo na Universidade de Zhejiang, que inseriu operações de inovação nas áreas rurais na China, com o intuito de encontrar o papel principal assumido pelas Universidades no sistema de inovação regional inclusiva. Os resultados mostram que as Universidades são capazes de desempenhar variados e importantes papéis na seleção, melhoria e difusão de tecnologia, disseminação e absorção de conhecimento, acesso à ciência e conhecimento tecnológico, serviço primário intermediário, no treinamento de mão de obra qualificada, na educação e oferta de grandes talentos em sistemas de inovação regional inclusivos. No mais, inovação inclusiva provê Universidades com vantagens competitivas, dificilmente replicável, mesmo que, fazendo máximo proveito de enormes consumo, produção e potencial de empreendedorismo contido na população pobre.

Palavras chave: inovação inclusiva, Universidade

\begin{abstract}
Аннотация
Инклюзивный рост - это необходимое решение для позитивных социальных изменений. В предыдущих исследованиях отмечалось, что университеты, играющие ключевую роль в других инновационных системах, не входят в инклюзивную инновационную систему. В настоящей статье сделана попытка изучения практического примера Чжэцзянского Университета, осуществляющего инклюзивную деятельность в сфере инноваций в сельских регионах Китая, с целью характеристики ключевой роли университета в региональной инклюзивной системе. По результатам исследования выявлено, что университет может играть различные и важные роли в процессах выбора, совершенствования и диффузии технологий, распространения и внедрения знаний, доступа к базе данных о науке и технологиях, посредничестве, обучении персонала, образовании и подготовке квалифицированных кадров в региональной инклюзивной системе. Кроме того, инклюзивные инновации обеспечивают дополнительное преимущество университету при решении проблем чрезмерного потребления, перепроизводства и создания предпринимательского потенциала среди бедных слоев населения.
\end{abstract}

Ключевые слова: инклюзивные инновации, университет

\section{Resumen}

Investigaciones recientes muestran que las universidades no suelen promover sistemas inclusivos de innovación. Este artículo examina el programa de innovación (Continued on next page) 
(Continued from previous page)

de la Universidad de Zhejiang que se dirige a áreas rurales de China y que busca promover un sistema inclusivo de innovación. Este caso ilustra cómo las universidades podrían desempeñar un papel fundamental en la configuración de sistemas inclusivos de innovación regional mediante la selección, el mejoramiento y la difusión de la tecnología, la difusión y la absorción del conocimiento, el acceso a la ciencia y la tecnología, la intermediación entre los actores de la innovación, la capacitación de trabajadores calificados, y el cultivo de talento. Destacamos aquí la manera en que el programa de innovación inclusiva de la Universidad de Zhejiang permitió a esa universidad ayudar a realizar el enorme potencial de consumo, producción, y emprendimiento de los hogares de bajos ingresos en las zonas rurales de China.

Palabras clave: innovación inclusiva, universidad

\section{Multilingual abstract}

Please see Additional file 1 for translation of the abstract into Arabic.

\section{Introduction}

Promoting the economic prosperity and abolishing poverty of the developing countries are the purpose of inclusive growth which guided by the idea of "building a community with a shared future for mankind." However, besides the poor infrastructure and weak industrial supply chains, the bottleneck for developing economies is education especially higher education, furthermore, the innovation capability. What we concern about is that whether there would be an appropriate innovation path for developing countries and what the university can do in it.

A new form of innovation that has been given the label 'inclusive innovation' is growing in developing countries. It has different names that reflects different emphases and has also been given other labels including 'pro-poor innovation', 'below-the-radar innovation, 'grassroots innovation,' 'BoP (base-of-the pyramid) innovation', and more (Horton 2008; Kaplinsky et al. 2009; Kaplinsky 2011; Cozzens and Sutz 2012; Ramani et al. 2012). Mainstream innovation was promoting development and creating wealth, while has in fact increased inequality between rich and poor, but inclusive innovation is trying to reduce inequality and poverty. Growth in the reality of this alternative or modified form of innovation has been matched by a growth of political and academic interests, driven particularly by both an actuality and a heightened perception of rising inequality. That inequality - as well as being inherently problematic- is also seen as holding back social and economic development in the long run (Stiglitz 2012).

There were growing engagement with inclusive innovation by international organizations such as the World Bank (2013), OECD (2013) and UNDP (2014). And by multinationals enterprises alongside large-and medium-sized firms, examples of these innovations include the Tata Nano, the Sakshat \$35 web notebook, the Hrudayalaya Heart Hospital, Discovery Health, Ushahidiand new business models in such activities as microfinance, rural electrification, crowd sourcing through mobile telephony, and health insurance (Chataway et al. 2014). And also, by national governments such as China and India (OAPM 2011). Inclusive innovation (and by extension inclusive growth) has been widely acknowledged as a goal of public and business policy. For 
example, the concept of inclusive growth and inclusive innovation is very much at the center of China's 12th Five Year Plan (2011-2015), and is taken as an attempt to transform Chinese economic and social development model. While the government of India cites inclusive growth as the overarching objective of legislation and budgetary allocation, it provides significant resources towards programs that '[reduce] poverty and [create] employment opportunities, access to essential services especially for the poor, equality of opportunity, and empowerment through education and skill development' (Planning Commission 2006).

Despite the progress of inclusive innovation made over the last decade, there is still much that we do not know yet. This paper is not trying to discuss these gaps in the literature or to review, once more, what we know about the models and paths of enterprises participating in inclusive innovation. Instead, our focus is on one particular aspect of this role of university that we believe formal institutions (such as universities and research institutes) are less forceful within low-income markets (Foster and Heeks 2013) or even are excluded from regional inclusive innovation system (Shao et al. 2011). Specifically, the research question of this paper will focus on what does the role of university play in regional inclusive innovation system.

Actually, there already are some researches on the role of university to the RIS or NIS, which can be illustrated into three aspects. Firstly, university will provide mounts of manpower that can intrigue the entrepreneurial action. Secondly, it can directly make the impact by the S\&T spillover. Thirdly, it will also lead the entrepreneurial culture to move forward, from 0 to 1 , also from 1 to 2 .

The remainder of the paper will be organized as follows: "Literature review" section will briefly review the literatures about inclusive innovation, method and analytical framework will be shown in "Analytical framework and method" section, background of case study and framework will be expatiated in "Analytical framework and method" section. More details of case study will be given in "Case study-evidence from China" section. In "Results" section, the paper will summarize the results. Finally, in "Conclusion and discussion" section, we will raise the conclusion and give discussion including the limitation of the paper.

\section{Literature review}

Trapped in a cycle of poverty and disenfranchisement are classified as living at the base of the pyramid (BoP) (Prahalad 2004). The terms 'inclusive innovation' and 'innovation for inclusive growth' interchangeably to address innovations that create or enhance opportunities to improve the wellbeing of those at the BoP. Gerard et al. (2012) define inclusive innovation as the development and implementation of new ideas which aspire to create opportunities that enhance social and economic wellbeing for disenfranchised members of society. Foster and Heeks (2013) define inclusive innovation simply as 'the inclusion within some aspect of innovation of groups who are currently marginalized'.

The other kind of definition is about which 'aspect' of innovation the marginalized group is to be included in. The main contrast is between those who think exclusion can be addressed simply in terms of innovation outputs vs. those who think marginalized groups must be included in innovation processes. A more differentiated view is shown in the 'ladder of inclusive innovation' (Heeks et al. 2013), there should be six 
level for inclusive innovation, that is, intention, consumption, impact, process, structure and post-structure. The levels are akin to steps on a ladder because each level involves a gradual deepening and/or broadening of the extent of inclusion of the excluded group in relation to innovation. In general, each level accepts the inclusion of the levels below, but pushes the extent of inclusion further (Heeks et al. 2013).

No matter how to define 'inclusive innovation', however, it focused on the structures and processes required to develop and deliver innovative technologies (goods and services) incorporating the needs and interests of the poor. Meanwhile, it has novel features including significant involvement of the private sector and global value chains, the development of poor consumers as an accessible mass market, growth of technological capabilities within developing countries and the involvement of new technologies (Kaplinsky 2011; Cozzens and Sutz 2012). Within the literature, one finds four aspects of inclusivity that are highlighted (Utz and Dahlman 2007; Altenburg 2009; Cozzens and Sutz 2012):

- Inclusivity of innovation precursors: for example that problems to be addressed by innovation are of relevance to the poor.

- Inclusivity of innovation processes: for example that the poor are involved in the development of innovative goods and services.

- Inclusivity of innovation adoption: for example that poor consumers have the capabilities to absorb innovations.

- Inclusivity of innovation impacts: for example that innovative goods and services have a beneficial effect on the livelihoods of the poor.

Reflecting the social fairness, building a community with a shared future for mankind and fully stimulating the social innovative vitality are the logical starting points of inclusive innovation (Fig. 1).

First, there are two principles needed to be considered when we reflect the social fairness. The principles are as follows:

(1) Equality of opportunities. Under the condition of fair equality of opportunity, all must share the benefits of innovative growth.

(2) Difference principle. Inclusive innovation is committed to making up for the "unfair starting point" caused by the "imbalance" of factors such as policy constraints, low educational level, and poor living environment (Ali I and Zhuang J 2007). In order to make sure the disadvantaged members of the community could be got attention, inclusive innovation focuses on the realization of "process fairness" and "result fairness."

Second, inclusive innovation also faces the challenge of different views. One of the query is why should we implement policy inclination and financial support to "BoP" group for they do not make a significant contribution to social development. The limitation of this query is denying the profound effect which the "BoP" group, as a "pyramid" base, has on maintaining the stability and normal functioning of the "ToP" community and even the whole community (Weidner et al. 2010).

Finally, the "top-down" innovation, which is from the "pyramid" top to the bottom, has been mainstream, while the "BoP" group has been neglected intentionally or 


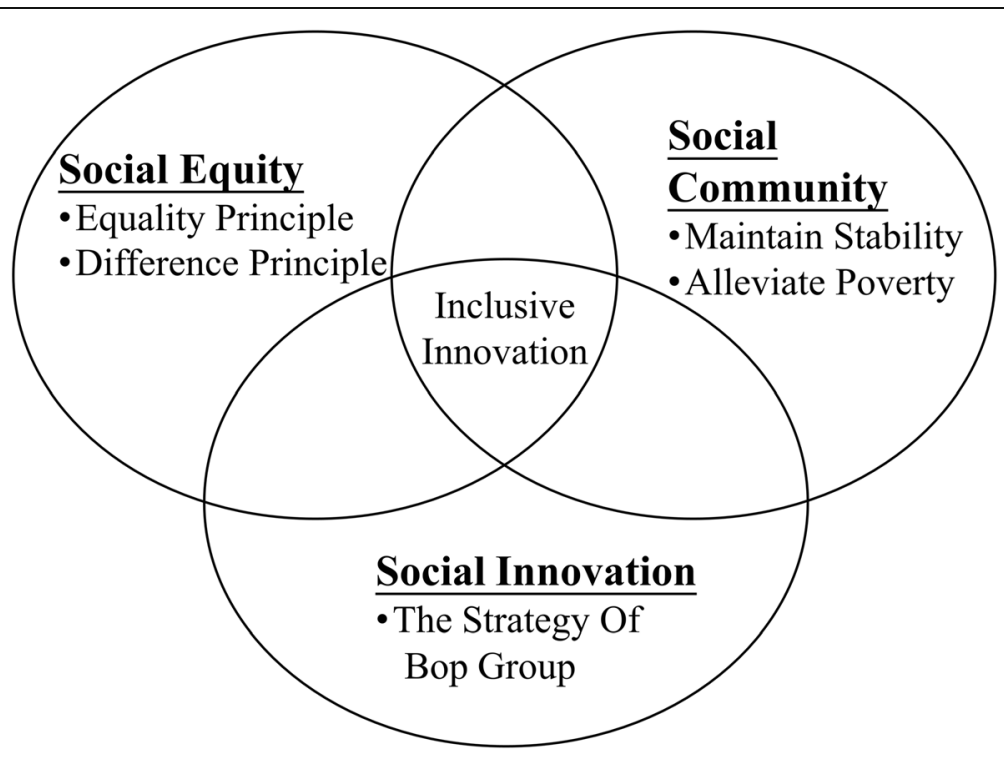

Fig. 1 The logical starting points of inclusive innovation

unintentionally. The "BoP" community is not only the beneficiary of "inclusive growth" but also the active participants and active practitioners of "social innovation" (Sen 1999). The innovation of "BoP" group did not depend on advanced technology or advanced knowledge, but acts as the ignored "social innovation vitality which stems from the rigid market demand that is easy to be omitted."

A number of authors have shown the potential for SoI(System of Innovation) ideas to be extended to encompass some of informal structures and processes typical of poor communities (for example, Chaminade et al. 2009), others have identified the potential relevance of SoI concepts for understanding innovation for the poor in developing countries (for example, Mackintosh et al., 2007; Altenburg 2009). That is because inclusive innovation faces challenges such as lack of market information, deficiency in knowledge and skills, imperfect institutional system, back ward infrastructure, limited access to financial services, and so on. All these constraints cannot be solved by one single enterprise, it needs support from many other stakeholders such as government, NGOs, local communities, research institutes, universities, financial institutes and intermediary institutions, to construct regional inclusive innovation system (Shao et al. 2011).

Looking at studies of inclusive innovation in developing countries, greater emphasis gradually focused on non-traditional, demand-side innovators. This includes informal sector workers (Nichter and Goldmark 2009) and lead users (Chéneau-Loquay 2010) who are incrementally innovating to adapt new technologies to the needs and circumstances of local consumers.

In some cases, Sol's conception of innovation actors has been extended, for example, to incorporate innovation intermediaries who stand between original suppliers and final consumers (Klerkx and Leeuwis 2009). They are mainly conceived as information/ knowledge brokers, typically connecting to formal research and development organizations (Winch and Courtney 2007). BoP markets are being served, a much richer network of intermediaries must be created, a network that must produce a whole set of 
minor adaptive innovations in order to ensure inclusivity: technology adoption and use and impact within those markets. Key intermediary roles, which have been essential to enable adoption and use of new technology by low-income consumers (Foster and Heeks 2013). Fleck (1993) utilizes the term 'innofusion' to cover the process of bringing inventions into use, then Gerard et al. (2012) raised the concept of 'inclusive innofusion': what has to date been rather a missing link between a new invention and its widespread adoption by low-income consumers.

In order to expand more innovative models without being too complicated, we define inclusive innovation as eliminating exclusive factors for economically poor or rights-excluded groups by taking advantage of the unique resources and capabilities and combining the advantages of production, technology, and knowledge of the BoP groups, so as to realize their social and economic development. The definition has the following points to be explained: First, as mentioned above, we believe that the object of inclusive innovation is very broad, but the main target now should be poor groups, especially those living in economically backward rural areas. Secondly, the definition highlights that innovation should be combined with local unique resource capabilities. Only in this way can local groups be truly integrated into innovation activities, thus effectively addressing inclusive issues. Innovative entities that can achieve this must have the advantages of production, technology, and knowledge that are closely related to the local community's resource capabilities and local industries. Finally, the definition emphasizes the sustainability of inclusive outcomes and the importance of inclusive processes. The sustainability of inclusive results means that the resources, capabilities, and opportunities of the poor are truly improved and they can continue to seek more benefits for themselves; for innovative subjects, this needs to provide "hematopoietic" functions for the poor, not just only "transfusion" is performed. Highlight the importance of the process and consider the process to be as important as the outcome, because even if the results of inclusive innovation often fail to meet expectations (Hall et al. 2012), the process is valuable for all aspects of the poor, and it itself reflects the spirit of social responsibility and fairness. In addition, it must be noted that low-cost, high-quality products and services provided by enterprises, NGOs, and other entities also fall into the category of inclusive innovation. These efforts are trying to eliminate exclusive factors, but may not reach the level emphasized in this definition.

SoI frameworks may therefore encompass a broad range of innovation actors, as inclusive innovation would require. Nevertheless, we need to supplement that theoretical potential with more specific detail: about who exactly the actors are in practice; how they connect to the supply and demand side of the system; and what the systemic contribution of their innovative activity is.

The relations between inclusive innovation system actors have in some ways been relatively "arms' length" market relationships; SoI frameworks of inclusive innovation systems have tended to focus on informal institutions, particularly those that deal directly with innovation (Foster and Heeks, 2013). Therefore, the ideas from the literature review are concluded: formal state institutions play a role in inclusive innovation but much less directly; those formal institutions are also less forceful within low-income markets, partly because of implementation gaps, and partly because of the rich informal institutional system that shapes behavior in and around these markets (Foster and Heeks 2013). 


\section{Analytical framework and method}

First, it should be recognized that different universities play different roles in the regional innovation systems (Boucher et al. 2003; Smith 2003; Lazzeroni and Piccaluga 2003). The university is repository of new knowledge, talent and other resources for innovation and economic development has been widely recognized. Recent research emphasis also changed, from emphasizing knowledge capitalization to focusing on establishing contact between the higher education sector and other sectors. University has been seen as institutional actor in regional innovation systems (Mowery and Sampat 2005). However, many studies on the role of higher education institutions (HEIs) in regional development see higher education institutions as sources of academic knowledge (first role) and providers of academic education (second role) rather than the builder of the regional system (third role) (Benneworth et al. 2009). This actually reflects a linear view of innovation, which believes that innovation begins with research, continuous improvement, and ultimately into production and commercialization. There is no feedback loop mechanism in traditional (linear) approach (Clark 1995). In the subsequent innovation researches, the core claim that has been widely proven through practice is to make innovative users become innovative partners. This enables new products and services to be better adopted because continuous feedback enables innovation to better meet user needs (Gardiner and Rothwell 1985; Lundvall 1988; Rothwell and Gardiner 1989). This evolutionary, non-linear, innovative perspective has been widely accepted (mainly contributed by: von Hippel 1976; Rothwell and Zegveld 1985; Kline and Rosenberg 1986; Clark 1995; Douthwaite 2002; Douthwaite et al. 2002). The comparison between the two approaches is shown in Table 1.

Therefore, as Caniëls and van den Bosch (2011) put forward, we should focus on how universities strengthen regional innovation systems. This is also the non-economic contribution of universities to regional innovation as stated by Boucher et al. (2003) and the "three-helix innovation" proposed by Etzkowitz and Leydesdorff (2000). This is a topic that has been widely discussed but rarely empirically studied.

Gunasekara (2006) made a prominent contribution to this research problem. Based on the triple helix model of university, industry, government relations (Etzkowitz and Leydesdorff 1999; Etzkowitz 2002a, 2002b), the literature on university engagement and the innovation systems literature (Holland 1999, 2001; Chatterton and Goddard 2000), the role of university in regional innovation system was divided into Generative Role and Developmental Role. Generative role means that the university provides limited and discrete knowledge diffusion in response to the demand of the society. The knowledge diffusion includes scientific and technological information, equipment and instrumentation, skills or human capital, networks of scientific and technological capabilities, and prototypes for new products and processes (Mowery and Sampat 2005). Developmental role means that the university is committed to a broader regional governance structure and seeks to shape the path of future regional economic development. The specific behaviors of developmental role overlaps with the production role, but it emphasizes the network construction that can shape regional institutional and social functions. Through this effort, the university will reshape the internal linkages of the regional innovation system and have a long-lasting impact on the system (Table 2). 
Table 1 Analytical approaches to HEl involvement

\begin{tabular}{|c|c|c|c|}
\hline & Traditional (linear) approach & \multicolumn{2}{|c|}{ Regional innovation system (non-linear, evolutionary) approach } \\
\hline Central idea & $\begin{array}{l}\text { Efforts in R\&D generate } \\
\text { innovation and } \\
\text { commercialization and } \\
\text { subsequently lead to better } \\
\text { economic performance }\end{array}$ & \multicolumn{2}{|c|}{$\begin{array}{l}\text { Interactive processes between varied and diverse actors, } \\
\text { networks, continuous learning processes, and } \\
\text { innovation-conducive institutions such as policy incentives } \\
\text { and trust give rise to economic growth, technological } \\
\text { dynamism, and competitiveness }\end{array}$} \\
\hline $\begin{array}{l}\text { View on } \\
\text { innovation }\end{array}$ & $\begin{array}{l}\text { Clear division of labor between } \\
\text { stages in the production process } \\
\text { Linear flow of processes: no } \\
\text { feedback loops in innovation } \\
\text { process }\end{array}$ & \multicolumn{2}{|c|}{$\begin{array}{l}\text { Innovation is iterative process characterized by trial } \\
\text { and error and incremental adaptation at every stage } \\
\text { Continuous interaction between different actors is crucial } \\
\text { Actively include users in innovation process } \\
\text { Continuous feedback loops from users to manufacturer }\end{array}$} \\
\hline $\begin{array}{l}\text { View on } \\
\text { the role } \\
\text { of HEl }\end{array}$ & $\begin{array}{l}\text { HEl as sources of academic } \\
\text { knowledge and providers } \\
\text { of academic education } \\
\text { Focus on key economic } \\
\text { performance indicators: } \\
\text { research excellence (papers) } \\
\text { and application of science } \\
\text { in manufacturing (patents) }\end{array}$ & \multicolumn{2}{|c|}{$\begin{array}{l}\text { HEl as regional system builders in direct interaction } \\
\text { with societal partners } \\
\text { Focus on system emergence } \\
\text { Innovation as inter-stakeholder learning } \\
\text { Emphasis on the role of institutions as being } \\
\text { conducive to regional innovativeness }\end{array}$} \\
\hline \multirow{2}{*}{\multicolumn{2}{|c|}{ Interactions between actors }} & The triple helix model & The engaged university \\
\hline & & $\begin{array}{l}\text { Relationships between universities, } \\
\text { industry and government are hybrid, } \\
\text { recursive and cross-institutional }\end{array}$ & $\begin{array}{l}\text { Active and initiating } \\
\text { role of universities in } \\
\text { regional development }\end{array}$ \\
\hline
\end{tabular}

Source: Marjolein C.J. Caniëls and Herman van den Bosch (2011)

In summary, the following points need to be noted and resolved in future research. First, university should "dominants" regional innovation and contributes to building regional innovation systems. Second, although the status and role of university in regional innovation systems are gaining more attention, the real challenge is how to build a regional institutional framework and discourse system that allows university to play a more significant role.

Table 2 Analyzing universities' contribution to the development of regional innovation systems

\begin{tabular}{|c|c|c|}
\hline $\begin{array}{l}\text { Key element of } \\
\text { regional innovation system }\end{array}$ & Generative role & Developmental role \\
\hline $\begin{array}{l}\text { Regional agglomeration, } \\
\text { or clustering, of industry }\end{array}$ & $\begin{array}{l}\text { - Knowledge capitalization and capital } \\
\text { formation projects, centered on firm } \\
\text { formation and co-location of new and } \\
\text { existing firms near the university }\end{array}$ & $\begin{array}{l}\text { - Entrepreneurial activities, as well } \\
\text { as regionally focused teaching and } \\
\text { research, not necessarily linked to } \\
\text { capital formation projects }\end{array}$ \\
\hline Human capital formation & $\begin{array}{l}\text { - Integration of education and } \\
\text { knowledge capitalization activities, } \\
\text { specifically, firm formation, through } \\
\text { teaching incubators } \\
\text { - Development of generic, advanced } \\
\text { training programs to support firm } \\
\text { formation and cross-institutional } \\
\text { mobility by organizations and people }\end{array}$ & $\begin{array}{l}\text { - Stronger regional focus on student } \\
\text { recruitment and graduate retention } \\
\text { - Education programs developed/ } \\
\text { adapted to meet regional skills needs } \\
\text { - Learning processes regionally-informed }\end{array}$ \\
\hline Associative governance & $\begin{array}{l}\text { - Driver of regional innovation strategy, } \\
\text { centered on knowledge capitalization } \\
\text { and capital formation projects; by } \\
\text { analyzing strengths and weaknesses } \\
\text { and bringing together industry and } \\
\text { government to forge innovation } \\
\text { strategy }\end{array}$ & $\begin{array}{l}\text { - Shaping regional networking and } \\
\text { institutional capacity, through staff } \\
\text { participation on external bodies; } \\
\text { provision of information and analysis } \\
\text { to support decision-making and bro } \\
\text { kering networking between national } \\
\text { and international contacts and key } \\
\text { regional actors }\end{array}$ \\
\hline Regional cultural norms & $\begin{array}{l}\text { - Tradition of university/industry } \\
\text { linkages, involving knowledge } \\
\text { capitalization }\end{array}$ & $\begin{array}{l}\text { - Tradition of university/industry } \\
\text { linkages, involving knowledge } \\
\text { capitalization and other research } \\
\text { collaborations }\end{array}$ \\
\hline
\end{tabular}


However, compared with the regional innovation system, there are some differences in the direct innovation subjects in the inclusive innovation system. The university is still an important innovation subject, but the departments within the university that participate in the regional innovation system and the inclusive innovation system are completely different. There is a general view that, in terms of technology, inclusive innovation focuses on the choice, application, and promotion of technology rather than on creation and R\&D, so scientific research institutions are replaced by the local group in the inclusive innovation. For example, The Creative Capacity Building (CCB) led by MIT in Tanzania, Uganda, Guatemala, and Haiti regarded the local group the innovation subject of innovation and technical inventor. At present, there are not enough literatures and practical cases to show that the role of business has changed. Therefore, this paper still holds that business is the mainly direct innovation subject.

In the regional innovation system, the government and the sci-tech intermediate organizations play a supporting role. There is sufficient practical evidence to show that in government-supported inclusive innovation, local governments and grassroots governments have played a role that cannot be ignored. Due to the lack of a perfect market environment, formal sci-tech intermediate organizations are rarely found in the inclusive innovation system, which are replaced by NGO, local associations, and authorities. Gao Tai-shan et al. (2014) argue that inclusive innovation serves the BoP and emphasize that Social Grassroots Organizations and individuals should be included in the innovation activities.

Based on the main view and the related theoretical literature of triple helix theory and the university participation in the regional innovation system, this article constructs the systematic framework of the university in the regional inclusive innovation (Fig. 2). Through this system framework, this article focuses on exploring the role and implementation paths (how to play a role) of university in the inclusive innovation system.

The paper summarizes the innovation behavior into four dimensions: Relationship, Research, Education, and Entrepreneurship.

The "relationship" dimension is the most basic behavior for universities, businesses, governments, and other subjects to carry out inclusive innovation, including "enhance mutual understanding" and "obtain credibility." "Enhance mutual understanding" refers to the initiative to integrate into the society, understand the real needs and realities of the local area, and lay the foundation for the subsequent behavior. This paper believes

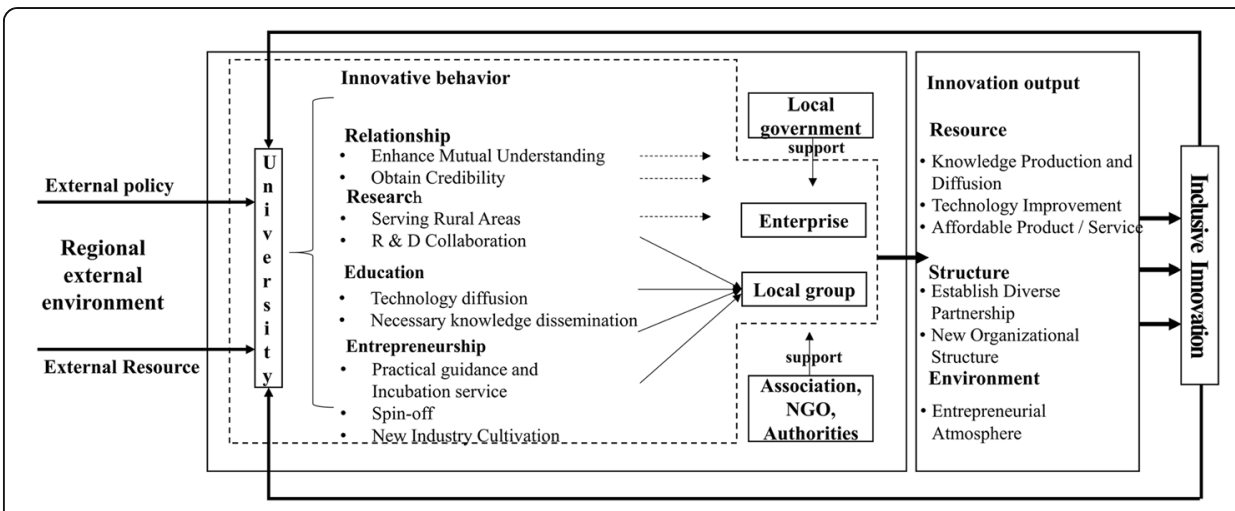

Fig. 2 The system framework of university involved in regional inclusive innovation 
that this behavior should be carried out extensively in the "poor areas" of the region rather than after identifying specific object. University can conduct spot investigation and write evaluation report with the cooperation of other innovation subjects. "Obtain credibility" refers to the establishment of a trust relationship with government, local group, NGO, associations, and authorities through interactive activities such as propaganda, communication, and so on.

The innovative behavior of university in the "research" dimension plays a most direct role in regional innovation, providing necessary knowledge, technology, talents, and other resources for innovation. "Research" dimension includes "serving rural areas" and "R\&D collaboration." In the narrow sense, "serving rural areas" means the university conducts research activities based on local social conditions. In the broad sense, it refers to the university formulating special research plans, and projects for inclusive innovation. "R\&D collaboration" means that the university admits local groups to participate in $R \& D$ and practical activity to truly meet local needs and solve local problems. Tijssen and Dijksterhuis (2015) points out a natural form of "R\&D collaboration," that is, the university research team itself includes researchers from poor groups who have mastered the situation knowledge in poor areas.

The "education" dimension includes "necessary knowledge dissemination" and "technology diffusion." "Necessary knowledge dissemination" refers to the fact that local groups cannot obtain the skills and knowledge to improve their living standards due to the scarcity of educational resources. The university will make up for this to enhance the ability and quality of local groups and promote the sustainable development of the local economy. "Technology diffusion" is also aimed at local group unable to further improve their living conditions due to lack of access to advanced production technology. The university conducts large-scale technology diffusion activities.

The "entrepreneurship" dimension mainly includes "practical guidance and incubation service." "Practical guidance and incubation service" is the behavior that universities provide on-site technical guidance or entrepreneurial resources to help local groups "get rich," enabling local groups to apply technology or implement entrepreneurship plans in practice, thereby generating income and improving living standards.

The study was a case study research (Eisenhardt 1989) realized in an immersion at the Zhejiang University (short for ZJU), which is considered to be the most important university and among the top 3 universities in China. The case materials were conducted through in-depth interviews complemented with institutional documents analysis, non-participant observation, and spot investigation. To provide greater consistency in the production of the study, some scientific premises were followed based on Eisenhardt's proposals:

Multiple investigators: three researchers, from different fields of knowledge, participated in the research, in order to bring complementary visions and reduce individual biases.

Multiple materials collection methods: starting from April 2016, we conducted a 2-month case study of the three directly affiliated institutions of Zhejiang University: the College of Agriculture and Biotechnology, ZJU (CAB), the Center for Agricultural and Rural Development, ZJU (CARD), and the local cooperation committee (LCC). In-depth interviews were conducted with 23 experts and institutional leaders. The texts and policy documents collected about Zhejiang University's participation in inclusive innovation were 17 in total. Meanwhile, in July 2016, we went to Anji County, Zhejiang 
Province, together with the person in charge of LCC of Zhejiang University, to conduct the spot investigation.

Under the guidance of the system framework of university involved in regional inclusive innovation (Fig. 2), the paper answered the question of "why and how university participates in inclusive innovation" and further verify the analytical framework, which is based on a thorough analysis of the case.

\section{Case study-evidence from China}

Zhejiang University located in the historical and picturesque city of Hangzhou. Zhejiang University is a comprehensive research university with distinctive features and a national as well as international impact. Research at Zhejiang University spans 12 academic disciplines. With 36 colleges/schools, Zhejiang University has 14 primary and 21 secondary national leading academic disciplines. This article will discuss the roles and functions of Zhejiang University in regional inclusive innovation from four dimensions, which are relationship, research, education, and entrepreneurship.

\section{Relationship dimension: enhance mutual understanding, obtain credibility}

Most of the inclusive innovation objects served by Zhejiang University are located in Zhejiang Province, and a few are outside Zhejiang province such as Guizhou, Zunyi, Meitan, Guangxi, and so on, which are Westward Movement ${ }^{1}$ region of Zhejiang University during the War of Resistance Against Japan. Zhejiang University, even in the process of Westward Movement, still actively helped the local community to improve infrastructure construction and train skilled labor. For example, in Jiangxi province, faculties and students tried their best to help the local people build flood control dams, set up Chengjiang School, and reclaim barren slopes. Local group with grateful mood named the dams as "ZJU dam." Therefore, Zhejiang University participates in inclusive innovation with historical genes; meanwhile, because of the special historical reasons, ZJU have been maintaining long-term relationship with these regions. Therefore, Zhejiang University's inclusive innovation is based on the full understanding of the object and lasting trust is the pre-practice elements as well.

\section{Research dimension: serving rural areas, R\&D collaboration}

It is a tradition for Zhejiang University to be the engine of social development. As early as the War of Resistance Against Japan in the 1930s, ZJU was forced to move west, ZJU made great contribution to the areas along the way. After the founding of new China, especially since the reform and opening up, the social service capacity of ZJU has been constantly improved.

The reason why ZJU kept giving back to the society can be narrowed into two aspects. The first one, thanks to the consciousness of scholars. The faculty of ZJU has the academic spirit of doing research based on the grounded issue. The other one is the complex of thanksgiving. Since the government provided plenty of policy and resources for ZJU, so in turn ZJU found that it is their own duty to feedback.

Facing national and regional needs, ZJU established a comprehensive social service system, including six sub-systems, such as talent cultivation and training, industrial technology research and promotion, agricultural technology extension services, public 
policy consulting, medical and health services, and international cooperation. Among these issues, it is the very work for ZJU to construct an inclusive innovation system via focusing on agriculture, rural areas, and peasants, which fully reflects that the research of ZJU is focusing on local area and trying to understand the needs of poverty group.

Meanwhile, in order to form an inexhaustible impetus to construct inclusive innovation system, enhance communication, and cooperation with local governments, groups, and enterprises, ZJU put efforts to build the inclusive innovation organization system. Among them, the local cooperation office is the entity of work, agricultural disciplines support is the foundation, agricultural think tank is the navigator, and classified management of the personnel system is the stimulus. Specifically as follows:

\section{(1) Entity: Local cooperation office}

Local cooperation office of Zhejiang University was founded in August 2005, which is the first professional institution in China which is especially responsible for the social service. The agricultural development through technology and education department is right for carrying on duty of inclusive innovation.

Moreover, in January 2006, the local cooperation committee (short for LCC) has been set up, deputy secretary of party committee of Zhejiang University standing as the team leader of the LCC, so that local cooperation office, under the leadership of LCC, could organize multi-sectoral participation to form the working group and coordinate resources within and outside ZJU and to work together to pushing the inclusive innovation forward.

(2) Basis: discipline

Promoting inclusive innovation cannot make bricks without straw. Zhejiang University always makes the impact relying on the solid disciplinary system, which reveals the unique advantage of science and technology when the university promotes inclusive innovation.

The College of Agriculture and Biotechnology (CAB), Zhejiang University was established in July, 1999 after the four universities in Hangzhou were merged to form a new Zhejiang University in 1998. There are five departments in the college, namely Agronomy, Plant Protection, Horticulture, Tea Science, and Applied Bioscience, which offer both undergraduate and graduate education programs. There are nine institutes established under the relevant departments namely Crop Science, Biotechnology, Insect Science, Pesticide and Environmental Toxicology, Vegetable Science, Pomology, Landscape Architecture, Tea Science, and Nuclear-Agricultural Science. There are 226 employees in the college including 81 professors and 79 associate professors.

Moreover, Zhejiang University gives full play to the advantages of interdisciplinary. The department offers a postdoctoral workstation, a doctoral degree program in agricultural and forestry economics and management, a master's degree programs in agricultural and forestry economics and management, a co-built master's program in industrial economics as well as two undergraduate programs in agricultural and forestry economics and management, and rural regional development. The department is actively involved in research areas such as Agricultural Industrial Organization and Institution, Resource and Land Management, Agricultural Economy and Policy, Agricultural Product Trade, and Supply Chain Management. 
(3) Navigator: think tank

The Center for Agricultural and Rural Development (CARD) was founded and directly under the lead of Zhejiang University. The mission of CARD is to exert the superiority of research in agricultural and rural modernization as well as the advantage of research in regional economy. The main functions of CARD are organizing research projects, scholastic communication, training up high-level talents, consultation for momentous decision, training of human resource, publishing the research works, and spreading research performance.

CARD is not only to promote inclusive innovation via providing intellectual guidance, but also make effective influence on government decision-making to win system space of inclusive innovation system.

(4) Stimulus: personnel system

After all, to promote inclusive innovation is basically to motivate the faculty and to cut loose the difficulties. Zhejiang University launched a series of policy in personnel system. Firstly, Zhejiang University formulates a "series of agro-technical popularization" teachers' title promotion, and appraisal system. Secondly, Zhejiang University has set up one type of faculty named "Qiushi distinguished promotion," encouraging high-level faculties to lead the transformation of high-tech achievements. Thirdly, Zhejiang University built the "agent" team, who are specialized in technology transformation.

\section{Education dimension: technology diffusion, necessary knowledge dissemination}

The four golden elements, including platform, discipline, think tank, and personnel system, make joint effort to promote inclusive innovation. When it comes to the science and technology popularization system of inclusive innovation, which means stepping into the real world, Zhejiang University have embodied three modes.

(1) Mode I: technology spillover-cooperation promotion center

Zhejiang University set up several cooperation promotion centers in rural areas. The centers mainly send chief experts in local leading agriculture industry, focusing on the introduction of advanced technology, and integrated innovation of suitable technology. They also pay great efforts to the experimental demonstration of new technology.

(2) Mode II: knowledge disseminating-agricultural science and education demonstration base

Zhejiang University set up more than 60 agricultural science and education demonstration bases in Zhejiang province. The demonstration bases relied on faculties' expertise to promote cooperation. In hence, professional knowledge disseminate from the experts to peasants, then they work together to facilitate joint development.

(3) Mode III: talents conveying-agricultural extension center 
Zhejiang University's agricultural extension center was set to focus on agriculture, rural areas, and peasants, and consisted of experts and professors of agro-technical popularization. Zhejiang University takes the center as an important platform service place. Through organization promotion team, Zhejiang University constantly conveys the talents to transform scientific and technological achievements. At present, nearly 100 teachers as well as the external marketing researchers serve as staff.

\section{Entrepreneurship dimension: practical guidance and incubation service, spin-off, new} industry cultivation

"Industry expanding-agricultural experts incubator" is the important mode of "practical guidance and incubation service" for the local. Zhejiang University encourages the promotion of faculties' knowledge, technology, and patent involved in the industrialization of agriculture science and technology. So agricultural experts incubators are established in Hangzhou, Huzhou, Lishui. The incubator integrate university, company, base and peasant household, make best configuration of land space, capital, and technology. It is necessary to say that the mode is successfully replicated in the western region.

\section{Performance}

In promoting the construction of inclusive innovation system, Zhejiang University fully relies on its academic strengths and makes inclusive innovation system presenting the booming trend of "a single spark can start a prairie fire" through serving characteristic industries and establishing research base in and out of the province.

\section{Technology transfer: agricultural technology transfer centers construction}

As of 2015, Zhejiang University transferred hundreds of technical achievements and provided training and consulting services for tens of thousands of local peasants through ten agricultural technology transfer centers in the poor rural areas in Zhejiang province and neighboring Jiangsu Province.

\section{Foster industry: support development of regional characteristic industries}

By depending on the firm basic science research and making agricultural technology promotion center and other bases as fulcrum, Zhejiang University combining with regional characteristics supports and fosters the development of industrial innovative development to achieve a two-dimensional coverage of region and industry (Table 3).

\section{Increase income: strong guarantee increasing of peasants' income}

In response to the national policy and local government, Zhejiang University creates substantial economic benefits for the local poor peasants during the process of allying local government to promote inclusive innovation system. According to incomplete statistics, gross output value agriculture and the peasants' per capita net income rose $10.8 \%$ and $12.8 \%$ annually in Huzhou, where urban-rural income ratio reduced from 2.11:1 in 2005 to 1.94:1 in 2013. With the help of Zhejiang University, Anji country of Zhejiang province establishes the tea export and process base whose annual production value of tea deep processing increase 250 million yuan and the export volume achieves 15 million dollars. Similarly, economic benefits of per acre increase more than 1000 
Table 3 Regional characteristic industries supported by ZJU

\begin{tabular}{|c|c|c|}
\hline Industry & Area & Product \\
\hline \multirow[t]{3}{*}{ Tea } & Anji & The export of tea and tea processing \\
\hline & Zunyi & Green tea, organic tea \\
\hline & Longquan & Oolong Tea \\
\hline Corn & Wuxing & Sweet, waxy corn \\
\hline \multirow[t]{2}{*}{ Sericulture } & Anji & \multirow{2}{*}{$\begin{array}{l}\text { Mulberry, silkworm breeding and promotion of new varieties, } \\
\text { comprehensive utilization and development of sericulture }\end{array}$} \\
\hline & Nanxun & \\
\hline \multirow[t]{5}{*}{ Fruit } & Nanxun & Grape \\
\hline & Deqing & Grape \\
\hline & Quzhou & Citrus \\
\hline & Lishui & Precocious sand pear \\
\hline & Huzhou & Watermelon, muskmelon, pumpkin \\
\hline \multirow[t]{5}{*}{ Aquatic products } & Wuxing & Testudinate \\
\hline & Xiangshan & Penaeusvannamei, swimming crab \\
\hline & Hangzhou & Turtle \\
\hline & Qingtian & Rice fish \\
\hline & GuizhouMeitan & Rice fish \\
\hline Edible fungi & Longquan & Pleurotus nebrodensis, black fungus, Ganoderma Lucidum \\
\hline \multirow{3}{*}{$\begin{array}{l}\text { Livestock and } \\
\text { poultry }\end{array}$} & Ninghai & Free range chicken \\
\hline & Jiaxing & Pig, chicken, duck \\
\hline & Guangxi Yizhou & \\
\hline \multirow{2}{*}{$\begin{array}{l}\text { Chinese herbal } \\
\text { medicine }\end{array}$} & Panan & \multirow{2}{*}{$\begin{array}{l}\text { Eight Zhes and rare and endangered medicinal plants (including } \\
\text { Dendrobiumcandidum), genuine medicinal materials, development } \\
\text { of traditional rare medicinal herbs and high-tech products }\end{array}$} \\
\hline & Changxing & \\
\hline
\end{tabular}

yuan in Zhejiang Wuxing corn base, where peasants' annual income increase 20 million yuan, forming a fresh corn processing industry with million tons production whose output value is 50 million yuan per year.

\section{Results}

According to the system framework of university involved in regional inclusive innovation and the case study of Zhejiang University, our research divides the role of university in inclusive innovation into four categories: first, product/service designer; second, technology promoter; third, practice/service provider; and fourth, innovation leader.

\section{Product/service designer}

Product/service designer refer to the universities that implement inclusive innovation under the dimensions of "Relationship" and "Research." The university should fully understand the needs of BoP groups, and focus on a specific need, such as lower-cost heating need, health care need under frequent power outages, and so on. The designed product or service should effectively meet local needs and have the potential for large-scale promotion. MIT's labs have consistently responded positively to global inclusive needs to design affordable and acceptable products and services for excluded or poor groups. For example, DIY Medical Equipment Toolkit (MEDIKits), designed to unleash the creativity of medical practitioners in developing countries, low-cost stoves 
that use pine needles as fuel, portable, pedal-driven washing machines, low-cost, solar-powered high-pressure sterilizer equipment, and so on.

\section{Technology promoter}

To ensure the BoP groups actually enjoy the benefits of inclusive innovation to achieve economic and welfare improvement, the university needs to invest time and money to promote and popularize inclusive products or technologies researched and developed independently or jointly with other institutions. In addition, the practice of providing educational resources and simply increasing the awareness, quality, and ability of the target group is also attributed to the category of technology promoters. In addition, simply providing educational resources and upgrading the knowledge, quality, and capabilities of BoP groups is also regarded as technology promoter. In collaboration with the Colombian Water Center, the Punjab Agricultural University promoted low-cost soil hygrometers through meetings with village leaders and farmers, conducting regional seminars, training in installation and use of soil hygrometers. Tsinghua University has established a large number of distance learning workstations throughout China, which transfer education and training resources to poor areas without compensation, and promote the improvement of the ability and quality of the poor groups themselves.

\section{Practice/service provider}

On the basis of promoting inclusive products or technologies, in order to play a role as a service provider, university should further promote local group to take full advantage of existing resources for entrepreneurial enrichment. The most basic content of the "Entrepreneurial" dimension is "practical guidance and incubation service," that is, universities provide intellectual support for the entrepreneurial practice of the local group. MIT D-Lab has set up a business incubator to provide entrepreneurs with life-based entrepreneurial resources. At the International Development Design Summit, the project brought together IDS from teachers and students, economists and engineers, professors and pastors, masons and mechanics, doctors, welders, farmers, and community organizers from more than 20 countries. The design team not only creates technology but also learns and shares entrepreneurial principles and creates businesses to enable poor groups to improve their living standards through technology production, use or sale.

\section{Innovation leader}

The innovation leader means that the university not only provides intellectual support in "Entrepreneurial" dimension, such as practical guidance and services, but also participates in setting up companies. Therefore, inclusive innovations carried out by universities will have a significant impact on the economic development of the entire region, and even form an atmosphere of entrepreneurial enrichment at the socio-cultural level. As the leader of innovation, since the content and form of the innovation is complicated, the university should set up a special agency to organize and implement inclusive innovations and establish a corresponding system to provide guarantees for the long-term and stable development of inclusive innovation. At this time, inclusive innovation has become a systematic project, and the dominant one is university. In the construction of the inclusive innovation and technology promotion system, Zhejiang University has formed working 
modes such as "Agricultural Promotion Center," "Agricultural Science and Education Demonstration Base," "Cooperative Promotion Center," and "Agricultural Experts Pioneer Park." The construction of inclusive innovation technology promotion system adheres to the combination of universities' science and technology innovation resources and local entrepreneurial resources; the combination of public welfare promotion and market-oriented services; the combination of demonstration base construction and characteristic industry development; and agricultural technology promotion, practical talent training, leading enterprises combine cultivation. In the end, it supported and fostered the innovation and development of eight industries in 18 regions within and outside the province, and achieved considerable regional economic returns and people's income growth.

\section{Conclusion and discussion}

After more than four decades of high growth, the Chinese economy is transforming from rapid growth to moderate growth. In order to create continuing dynamic growth, it is important to build up momentum for growth both internally and externally based on new competitive capacity, which is inclusive growth or inclusive innovation. Some universities, such as Zhejiang University, had been exploring the paths to serve more people, especially the excluded group or BoP group. Meanwhile, the new growth frontier for the global economy lies in the developing countries, and China needs to take a bigger role in global affairs, not only exporting China's production capacity but also trying to export the high education and innovation. No individual country alone can build a well-connected infrastructure network or an inclusive benefit-sharing strategic alliance, but a set of collective agendas can help to mobilize and pull together resources through cooperation, either among the partners or through newly built institutions.

In this paper-drawing on the case of Zhejiang University in China-we may learn from the case study that university can play roles in selection, improvement and diffusion of technology, dissemination and absorption of knowledge, access to science and technology knowledge, primary intermediary service, training skilled labor, and educating high-level talents in regional inclusive innovation system. Hence, university is proved to make great impact to enhance the regional inclusive innovation system. The reason why university in China exerts all the effort to inclusive development is largely determined by the fundamental social needs. Moreover, the regional entrepreneurial culture somehow fosters the cultural state of continually feedback to society. In turn, via the reform of governance structure, this kind of cultural state can be soundly put into action. Because of the very interaction, university gradually grasps the leading role in the regional development; simultaneously, university gains lots of upgrading via the entrepreneurial service. As the development status and innovation system situation of China and developing countries, specifically in five aspects (Table 4): the competitiveness, skilled workers availability, the manufacturing industry, and technology applicant (Cai and Liu 2015). Therefore, the role of university in inclusive innovation activities summarized from Zhejiang University case is homogeneous and portable. For a long period of time, when universities participate in inclusive innovation activities, no matter domestic or other developing countries, they should take the responsibilities of intelligence technology promotion, intellectual services, and personnel training, and so on.

However, the paper has some limitations, firstly yet there has been a lack of field databased application of these ideas, to systematically understand whether standard 
Table 4 Development status and consistency in innovation system context of China and the developing countries

\begin{tabular}{ll}
\hline Factor & Consistent performance \\
\hline Basis of competitiveness & Using technology to learn and standardize production competition \\
Availability of skilled labor & Lack of skilled labor \\
Position of skilled industry & Manufacturing cheap products key pillar of economy \\
in economy & \\
Use of technology and skills & $\begin{array}{l}\text { Focusing on simple manufacturing tasks using little technology } \\
\text { and much }\end{array}$
\end{tabular}

Source: the authors adapted from Kroll and Liefner (2008) and Eun et al. (2006)

ideas are applicable or whether the particular features of inclusive innovation for, with and by the poor would require us to modify these ideas. Moreover, we just focus on the internal factor of universities that involved in the inclusive innovation, some important external factors such as international political, cultural, economic factors, which will play a much more important role in influencing the university on cooperation or involvement in inclusive innovation.

\section{Endnotes}

${ }^{1}$ Since the outbreak of the War of Resistance Against Japan, Zhejiang University was forced to move westward to Guizhou, passing six provinces: Zhejiang province, Jiangxi province, Hunan province, Guangdong province, Guangxi province and Guizhou province, which is called "Long March of Culture".

\section{Additional file}

Additional file 1: Translation of the abstract into Arabic. (PDF $46 \mathrm{~kb}$ )

\section{Abbreviations \\ BoP: Base-of-the pyramid; CAB: The College of Agriculture and Biotechnology; CARD: The Center for Agricultural and Rural Development; LCC: The Local Cooperation Committee; ZJU: Zhejiang University}

\section{Acknowledgements}

The paper is supported by Humanities and Social Sciences Fund of Chinese Ministry of Education (No. 17JDGC038) and Special Research Project for Liberal Arts Faculties in Zhejiang University: Systematic Developing Path of Engineering Creativity.

Funding

The research reported in this article was funded by Chinese Ministry of Education and Zhejiang University.

\section{Availability of data and materials}

All are available.

\section{Authors' contributions}

All authors wrote parts of the initial manuscript, read, and approved the final manuscript.

\section{Authors' information}

YAO Wei, Associate Professor of Zhejiang University, Assistant to Dean of Research Institute of China's Science, Technology and Education Policy, Email: ywzju@126.com, Phone:0086-13,735,817,821, Address: Room 1205-5, Administration Building, Zijingang Campus, Zhejiang University, Hangzhou, Zhejiang, China. P.R; LI Heng, Ph.D Candidate of School of Public Affairs, Zhejiang University, Email: leeheng@zju.edu.cn, Phone: 0086-18,868,106,943, Address: Room 905,Administration Building, Zijingang Campus, Zhejiang University, Hangzhou, Zhejiang, China. P.R; WENG Mosi, Ph.D Candidate of School of Public Affairs, Zhejiang University, Email: mosi@zju.edu.cn, Phone: 0086-13,675,892,301, Address: Room 905,Administration Building, Zijingang Campus, Zhejiang University, Hangzhou, Zhejiang, China. P.R. 


\section{Publisher's Note}

Springer Nature remains neutral with regard to jurisdictional claims in published maps and institutional affiliations.

\section{Author details}

${ }^{1}$ Research Institute of China's Science, Technology, and Education Policy, Zhejiang University, Room 1205-5, Administration Building, Zijingang CampusHangzhou, Zhejiang, People's Republic of China. ${ }^{2}$ School of Public Affairs, Zhejiang University, Room 905, Administration Building, Zijingang CampusHangzhou, Zhejiang, People's Republic of China.

Received: 18 March 2018 Accepted: 6 November 2018

Published online: 17 December 2018

\section{References}

Ali, I., \& Zhuang, J. (2007). Inclusive growth toward a prosperous Asia: policy implications. Asian Development Bank Altenburg T (2009) Building inclusive innovation systems in developing countries: challenges for IS research. In: Lundvall BA Joseph KJ, Chaminade C (eds) Handbook on innovation systems and developing countries: building domestic capabilities in a global context. Cheltenham. Edward Elgar, UK, pp 33-57

Benneworth P, Coenen L, Moodysson J, Asheim B (2009) Exploring the Multiple Roles of Lund University in Strengthening Scania's Regional Innovation System: Towards Institutional Learning? Eur Plan Stud 17(11):1645-1664

Boucher G, Conway C, Van Der Meer E (2003) Tiers of engagement by universities in their region's development. Reg Stud 37(9):887-897

Cai Y, Liu C (2015) The roles of universities in fostering knowledge-intensive clusters in chinese regional innovation systems. Sci Public Policy 42(1)

Caniëls MCJ, van den Bosch H (2011) The role of Higher Education Institutions in building regional innovation systems. Pap Reg Sci 90(2):271-286

Chaminade C, Lundvall BA, Vang J, Joseph KJ (2009) Designing innovation policies for development. In: Handbook on innovation systems and developing countries: building domestic capabilities in a global context. Cheltenham. Edward Elgar, UK, pp 360-378

Chataway J, Hanlin R, Kaplinsky R (2014) Inclusive innovation: an architecture for policy development. Innov Dev 4(1):33-54

Chatterton P, Goddard J (2000) The Response of Higher Education Institutions to Regional Needs. Eur J Educ 35(4):475-496

Cheneau-Loquay A (2010) Innovative ways of appropriating Mobile telephony in Africa. ITU, Geneva

Clark N (1995) Knowledge systems - interactive nature of knowledge systems: Some implications for the third world. Sci Public Policy 22:249-258

Cozzens S, Sutz J (2012) Innovation in informal settings: a research agenda. In: Ottawa: IDRC

Douthwaite B (2002) Enabling innovation: A practical guide to understanding and fostering technological change. Zed Books, London

Douthwaite B, Keatinge JDH, Park JR (2002) Learning selection: an evolutionary model for understanding, implementing and evaluating participatory technology development. Agric Syst 72(2):109-131

Eisenhardt KM (1989) Building theories from case study research. Acad Manag Rev 14(4):532-550

Etzkowitz H (2002b) MIT and The rise of entrepreneurial science, vol 03. Routledge

Etzkowitz H (2002a) Incubation of incubators: innovation as a triple Helix of university-industry-government networks. Sci Public Policy 29(2):115-128

Etzkowitz H, Leydesdorff L (1999) The future location of research and technology transfer. J Technol Transfer 24(2-3):111-123

Etzkowitz H, Leydesdorff $L$ (2000) The dynamics of innovation: from national systems and 'mode 2' to a triple helix of university-industry-government relations. Res Policy 29:109-123

Eun JH, Lee K, Wu G (2006) Explaining the "University-run enterprises" in China: A theoretical framework for universityindustry relationship in developing countries and its application to China. Res Policy 35(9):1329-1346

Fleck J (1993) Innofusion: feedback in the innovation process. In: Stowell FA, West D, Howell JG (eds) Systems science. Plenum Press, New York, pp 169-174

Foster C, Heeks R (2013) Conceptualising inclusive innovation: modifying Systems of Innovation Frameworks to understand diffusion of new technology to low-income consumers. Eur J Dev Res 25:333-355

Gao T-s et al (2014) The measurement of China's regional inclusive innovation performance: theoretical model and its empirical verification. Stud Sci Sci 32(4):613-621

Gardiner P, Rothwell R (1985) Tough customers: good designs. Des Stud 6(1):7-17

Gerard G, McGahan AM, Prabhu J (2012) Innovation for inclusive growth: towards a theoretical framework and a research agenda. J Manag Stud 49(4 June):661-684

Gunasekara C (2006) Reframing the role of universities in the development of regional innovation systems. J Technol Transfer 31:101-113

Hall J, Matos S, Sheehan L, Silvestre B (2012) Entrepreneurship and Innovation at the Base of the Pyramid: A Recipe for Inclusive Growth or Social Exclusion? J Manag Stud 49(4):785-812

Heeks R, Amalia M, Kintu R, Shah N (2013) Inclusive Innovation: Definition, Conceptualization and Future Research Priorities, IDPM Development Informatics Working Paper no.53. University of Manchester, UK

Holland BA (1999) From murky to meaningful: The role of mission in institutional change. In: Colleges and universities as citizens, pp 48-73

Holland BA (2001) Toward a definition and characterization of the engaged campus: Six cases. Metrop Univ 12(3):20-29

Horton D (2008) Facilitating pro-poor market chain innovation. Papa Andina, Lima

Kaplinsky R (2011) Schumacher meets Schumpeter: appropriate technology below the radar. Res Policy 40(2):193-203

Kaplinsky R et al (2009) Below the radar: what does innovation in emerging economies have to offer other low-income economies? Int J Technol Manag Sustain Dev 8(3):177-197 
Klerkx L, Leeuwis C (2009) Establishment and embedding of innovation brokers at different innovation system levels. Technol Forecast Soc Chang 76(6):849-860

Kline SJ, Rosenberg N (1986) An overview of innovation, The positive sum strategy harnessing technology for economic growth. National Academic Press, Washington DC

Kroll H, Liefner I (2008) Spin-off enterprises as a means of technology commercialisation in a transforming economy-Evidence from three universities in China. Technovation 28(5):298-313

Lazzeroni M, Piccaluga A (2003) Towards the Entrepreneurial University. Local Econ 18(1):38-48

Lundvall BÅ (1988) Innovation as an interactive process: From user-producer interaction to the national innovation systems, Technology and economic theory. Pinter, London

Mowery DC, Sampat BN (2005) Universities in National Innovation Systems. Oxf Handb Innov 1999(100):1-112

Nichter S, Goldmark L (2009) Small firm growth in developing countries. World Dev 37(9):1453-1464

OAPM (2011) Towards a more inclusive and innovative India. Office of the Advisor to the prime minister. Government of India, New Delhi

OECD (2013) Innovation and inclusive development. OECD, Paris https://www.oecdilibrary.org/docserver/5k4dd1rvsnjj-en. pdf?expires=1543389664\&id=id\&accname=guest\&checksum=4D260F089861 AAE9652058CA02C35C24

Planning Commission (2006) Eleventh five year plan. Planning Commission, New Delhi

Prahalad CK (2004) The fortune at the bottom of the pyramid: eradicating poverty through profits. Wharton Business School Publishing, Philadelphia, PA

Ramani SV, Sadreghazi S, Duysters G (2012) On the diffusion of toilets as bottom of the pyramid innovation: lessons from sanitation entrepreneurs. Technol Forecast Soc Chang 79(4):676-687

Rothwell R, Gardiner P (1989) The Strategic Management of Reinnovation. R\&D Manag 19(2):147-160

Rothwell R, Zegveld W (1985) Reindustrialization and technology. Longman, M.E. Sharpe

Sen A (1999) Development as freedom. Anchor Books, New York, pp 5-10

Shao X, Xing X-q, Tong Y-h (2011) Research on inclusive regional innovation system. China Popul Resour Environ 21(6):24-27

Smith L (2003) Knowledge Organizations and Local Economic Development: The Cases of Oxford and Grenoble. Reg Stud 37(9):899-909

Stiglitz JE (2012) The Price of inequality. WW Norton, New York, NY

Tijssen R, Dijksterhuis M (2015) African Universities and Inclusive Innovation: Case Studies in the Western Cape Province of South Africa

UNDP (2014) Inclusive Development. UNDP, New York, NY http://www.undp.org/content/undp/en/home/sustainabledevelopment/development-planning-and-inclusive-sustainable-growth/inclusive-growth\%2D\%2Daddressing-inequalityand-social-exclusion.html

Utz A, Dahlman C (2007) Promoting inclusive innovation. In: Dutz MA (ed) Unleashing India's innovation: toward sustainable and inclusive growth. World Bank, Washington DC, pp 105-129

von Hippel E (1976) The dominant role of users in the scientific instrument innovation process. Res Policy 5(3):212-239

Weidner KL, Rosa JA, Viswanathan M (2010) Marketing to subsistence consumers: Lessons from practice. J Bus Res 63(6):559-569 Winch GM, Courtney R (2007) The Organization of Innovation Brokers: an international review. Tech Anal Strat Manag 19(6): $747-763$

World Bank (2013) Shared prosperity. World Bank, Washington, DC http://www.worldbank.org/en/news/feature/2013/05/08/ shared-prosperity-goal-for-changing-world

\section{Submit your manuscript to a SpringerOpen ${ }^{\circ}$ journal and benefit from:}

- Convenient online submission

Rigorous peer review

- Open access: articles freely available online

- High visibility within the field

- Retaining the copyright to your article

Submit your next manuscript at $\boldsymbol{\nabla}$ springeropen.com 